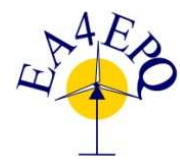

International Conference on Renewable Energies and Power Quality (ICREPQ'13)

Bilbao (Spain), 20 ${ }^{\text {th }}$ to $22^{\text {th }}$ March, 2013

Renewable Energy and Pourer Qualiny. Fournal (RE\&PQJ)

ISSN 2172-038 X, No.11, March 2013

\title{
An overview of renewable energy technologies and hydrogen economy
}

\author{
Kary Thanapalan ${ }^{1,2}$, Fan Zhang ${ }^{2}$, Stephen Carr ${ }^{2}$, Giuliano Premier ${ }^{1,2}$ Alan Guwy ${ }^{2}$, Jon Maddy \\ ${ }^{1}$ Sustainable Environment Research Centre (SERC) \\ Faculty of Advanced Technology \\ University of Glamorgan \\ Pontypridd CF37 1DL, UK \\ Phone/Fax number: +0044 1443 654294, e-mail: kthanapa@glam.ac.uk \\ ${ }^{2}$ Sustainable Environment Research Centre (SERC) \\ Renewable Hydrogen Research \& Demonstration Centre \\ University of Glamorgan \\ Baglan Energy Park, Baglan \\ Port Talbot SA12 7AX, UK \\ Phone/Fax number: +0044 1639814523
}

\begin{abstract}
This paper presents an overview of renewable energy technologies, the hydrogen economy, and the impact of renewable energy technologies penetration on energy price. The paper begins by presenting an overview of different energy sources and the impact from hydrogen as a fuel into the energy market along with the problems associated with hydrogen energy. The work proceeds to investigate the applications of hydrogen as a fuel and its effects on investment policy in energy industry.
\end{abstract}

\section{Key words}

Renewable energy, Hydrogen economy, Energy sources, Sustainability, Hydrogen production and storage

\section{Energy supply technologies}

Continuing population growth and rising incomes lead to greater energy consumption, as well as more waste. Over the next few decades, the number of people who are affected by energy shortages is likely to increase several fold. Economically viable methods for renewable energy production can reverse this trend and ensure a continuous supply of energy. The increasing global energy demand and concern about the environmental impact of excess usage of fossil fuels have progressively increased the interest in energy from renewable energy sources. The development of renewable energies into the energy market is being pursued by several governments around the world in an effort to abate climate change, provide security of energy supply and reduce air pollution. In order to reduce the carbon emission, policy makers set some high targets to achieve. The current UK target against 1990 emissions is 34\% cut in emissions by 2020 . Furthermore, an $80 \%$ cut in emissions by 2050 is also targeted [1], [2].
There are many different energy sources existing. These can be grouped into three main categories such as fossil fuels, nuclear and renewable energy sources [2], [3]. Fossil fuels include coal, petroleum and natural gas/oil amongst others. Nuclear fission and fusion are considered as the nuclear energy sources [4], [5]. In general renewable energy is a clean and non-polluting energy and it's produced from sustainable energy sources [6]. The main renewable energy sources are solar, wind, wave, tidal, bio-energy and geothermal energy [7], [8], [9], [10].

Among these renewable sources, solar energy is one of the most promising energy sources for widespread application [11], [12], [13]. The reason for that includes its free access and abundance for most of the places in the world. Due to its intermittency and fluctuation, one of the important research challenges is to improve the system's efficiency and performance. However, it is evident that the solar system has been deployed widely and more and more organisations and people are benefiting from installing photovoltaic panels, which converts the solar energy to electrical energy [14]. It is estimated that the PV industry had a global total of $40 \mathrm{GW}$ capacity which is a significant compared with other renewable energy sources [12], [14].

Wind energy is also widely distributed but wind regimes differ significantly both within and between regions, and variations in wind speed can have a profound effect on energy output [15], [16], [17]. Grid connected wind power, from large turbines has seen rapid market growth recently. The amount of wind power currently installed is about $200 \mathrm{GW}$ with a growth rate of $40 \mathrm{GW}$ installed annually worldwide. However the annual growth rate differs considerably between regions even within a country. For example, expected annual growth rate is $33 \%$ in Wales and $22 \%$ in the UK [17]. Increasing the amount of wind power has significant effects on the electrical grid 
that has to carry the additional load. Large erratic fluctuations of wind power are a common characteristic and have to be compensated by spinning reserve or increased storage facilities. Besides conventional storage systems (e.g. pump storage stations, battery/flywheel storage) in recent years a particular research emphasis has been placed on hydrogen storage systems and associated consumption in electric drive vehicle fleets [17], [18], [19], [20], [21], [22].

Wave energy is a clean and renewable energy source and its potential is huge, as the energy per meter of wave front is substantial along large reaches of oceanic coastline and wave energy machines are typically able to convert about $75 \%$ of available wave power into useful energy [23], [24]. The biggest problem wave energy faces is the cost, but the technology improves and the cost of the production drops it will develop into a competitive renewable source of energy [24].

Tidal energy is a form of hydropower that converts the energy of tides into useful forms of energy [25]. Tidal energy is generated by potential energy from changes of water level and tidal stream. The relative celestial movements of the earth, the sun and the moon cause a periodic movement of the sea surface, and such fluctuation of the sea water called tide. Tidal energy could provide a quarter of the UK's electricity, but the cost is expected to be very high. The UK has some of the fiercest tidal currents in the world, but the latest report on Renewables from the Committee on Climate Change (CCC) states that the tidal turbines will deliver energy at a higher cost than PV in 2040. The CCC offers a view as to the output of a tidal turbine, suggesting that in a 'high' case the figure will be $40 \%$. That is, the average electricity output of a $1 \mathrm{MW}$ turbine over the course of a year will be $400 \mathrm{~kW}$. But with sustained research and development effort and financial investment through government support, tidal energy may become one of the UK's most important industries [7], [26], [27].

Bio-energy production and usage presents a more complicated outlook than the other renewable energy technologies [28], [29], [30]. This is due analysts taking different positions about the likely impacts of significant bio-energy use. However, bio-energy is widely seen as an important renewable energy resource, with a potentially significant role in enabling decarbonisation in the UK and globally [28], [29].

Geo-thermal energy is basically, the heat energy from the Earth and it can be found almost anywhere. Many regions of the world are already tapping geothermal energy as an affordable and sustainable solution to reducing dependence on fossil fuels, and global warming [27]. However, only a handful of locations exist across the world that are capable of producing viable and efficient levels of electricity from geothermal energy sources and as a result of this, in 2007 , less than $1 \%$ of the world's electricity supply was produced from geothermal sources. But, recent technological advances have dramatically expanded the range and size of viable resources, especially for applications such as home heating, opening the potential for widespread exploitation [7], [16].

Hydrogen is another alternative to cope with the increased global energy demand [31], [32], [33]. It is an energy carrier (an energy carrier moves and delivers energy in a usable form from producers to consumers) and store, so can help with variability and aggregation of a number of different energy sources plus hydrogen vehicles [34]. Its produce no harmful emissions when used in a fuel cell. The remaining section of this paper investigates the hydrogen energy together with a cost analysis in terms of both commercial and technological maturity.

\section{Renewable Hydrogen Energy}

The attraction of using hydrogen as an energy carrier is growing rapidly in order to satisfy the increasing energy needs due to the growing global energy demands and energy shortages with high efficiency, lower emissions and low fuel usage [1]. Hydrogen is of considerable relevance in such circumstances, since hydrogen produced from renewable sources has the flexibility to be used as a clean, safe and convenient transport fuel [19]. Several automobile manufacturers have committed to develop vehicles using hydrogen. If hydrogen is prepared without using fossil fuel inputs, vehicle propulsion would not contribute $\mathrm{CO}_{2}$ emissions. The drawbacks of hydrogen use are low energy content per unit volume, high tankage weights, very high storage vessel pressures, the storage, transportation and filling of gaseous or liquid hydrogen in vehicles, the large investment in infrastructure that would be required to fuel vehicles, and the inefficiency of production processes. Significant research efforts have been made to resolve the problems encountered. For example, the renewable hydrogen research and demonstration centre at the University of Glamorgan, UK, focuses on the production of renewable hydrogen in the following methods; solar powered hydrogen production, optimising the electrolyser performance, wind power, and bio-hydrogen production from renewable biomass or waste. Renewably produced hydrogen, accessible from a number of production routes with no carbon emissions is an ultimate target [6], [19]. Similarly to this project, there are several research and demonstration projects carried out around the world. Apart from the transportation sector, the effort to increase the amount of renewable energy we use is important to a great variety of other sectors as well; especially in the area of housing and building, and process and production industries [14], [17]. Focus lies both on the increase of efficiency and on the change from fossil and nuclear fuels to more sustainable solutions. One way to integrate a sustainable solution to the energy market is through hydrogen [1], [18], [35], [36]. It is therefore, essential to search for design and operating conditions which lead to reduction of energy dissipation and consequently lower hydrogen production cost to promote the hydrogen technologies [37]. In addition to the energy consumption, the cost of the technology and final cost of the hydrogen fuel determine the place of hydrogen energy in the energy market [19], [20], [38], [39]. 


\section{Cost analysis and hydrogen economy}

Energy cost in any given renewable energy source depends on the system's design and operation characteristics and the quantity and type of losses encountered during production and delivery to the end user [16], [19]. In this section the energy cost for the hydrogen is analyzed with reference to the other renewable energies such as solar and wind energy.

Investing in renewable energy could lead to economic growth and ensure energy security. Furthermore, it can result in technological advancement, create new business and jobs [40]. According to International Energy Agency (IEA) Levelised Cost of Energy (LCOE) of solar photovoltaic was $£ 162$ pounds per MWh in 2008 which is now $£ 137$ pounds per MWh and predicted to be reduced to be only $£ 28$ per MWh by 2030 . In the long term, a third generation of PV materials, currently at the laboratory stage, may be able to deliver even more radical reduction in cost [12], [13]. Similarly for the case of wind energy cost is now about $£ 30$ pounds per MWh and expected to be decreased to $£ 18$ pounds per MWh. Thus, it should be noted that investment in renewable energy reduces total costs and takes part in economic growth [15], [39].

An economically viable way to start using the renewable energy (in most cases) is in the production of electricity. The cost of electricity produced by wind turbines and PV modules can be calculated by the following equation [7], [41].

$$
\begin{array}{r}
C_{e}=\left(C_{i_{k}} \times C_{r}\right) \tau \cdot C_{k}^{-1}+\left(C_{0}+C_{m}\right) \\
\text { With } k=\text { wind, } P V
\end{array}
$$

Where, $C_{e}$ is the cost of electricity generated $(\mathfrak{f} / \mathrm{kWh})$, $C_{i_{k}}$ is the cost of installed capacity for the wind turbines or PV modules, $C_{r}$ is the capital recovery factor, $\tau$ is the operational time, $C_{k}$ is the capacity factor. This capacity factor for wind turbines is generally defined as the ratio of the annual average power output to the rated power output. Similarly for the PV cells, $C_{P V}$ is defined as the ratio of the annual average power output to the peak power output. $C_{0}$ is the operational cost and $C_{m}$ is the maintenance cost.

In the case of hydrogen energy, determining the cost of hydrogen is very difficult in the current stage of the hydrogen economy [19]. The calculation of the price involves assumption of mass production, taxes, and the way in which hydrogen produced. For example, through wind farm or via electrolysis etc, It should be noted that in order to achieve the benefits from a hydrogen economy, hydrogen need to be produced from a renewable energy source [1]. If hydrogen is produced from wind power for the purpose of vehicle refuelling, the distance between the hydrogen fueling station and wind to hydrogen production facility play a significant role in the determination of the final cost of the hydrogen energy [17]. Furthermore, the hydrogen economy is a network composed of three functional steps; production, storage and consumer (usage), therefore it is important to consider the costs of the entire fuel cycle from well to wheels, otherwise the cost of hydrogen energy can differ significantly. By adopting the well to wheels approach, it is possible to estimate the potential cost of carbon free hydrogen generated from renewable sources relative to the use of gasoline in typical vehicles today [7], [42]. The relationship of the estimated cost of carbon free hydrogen is given by the following equation;

$$
C_{H_{2}}=\eta^{-1} C_{r e} C_{c e}^{G}
$$

Where, $C_{\mathrm{H}_{2}}$ is the cost of carbon free hydrogen (£/gallon), $\eta$ is the total efficiency and is dependent on the way the renewable hydrogen is produced, it may include electrolyzer conversion efficiency and hydrogen storage efficiency etc. $C_{r e}(£ / k W h)$ is the reference cost of renewable energy such as wind or $\mathrm{PV}, C_{c e}^{G}(k W h)$ is the capacity of chemical energy in a gallon of gasoline (i.e, the capacity of gasoline gallon equivalent). By using this formula and comparison of cost analysis, the cost of hydrogen per $\mathrm{kg}$ in a variety of scenarios can be estimated, for example, hydrogen from wind and solar cost about $5-6 £ / \mathrm{kg}$ and $3-5 £ / \mathrm{kg}$ respectively. It is an indication that the hydrogen economy is within sight, but how fast we get there will depends on many factors such as commitments and investment. Furthermore, energy policy and progress to date play a key role to the successes of a hydrogen economy [39]. In the next section of the paper the effects of investment policy in (hydrogen) energy industry is investigated.

\section{Energy policy}

Government energy policy is a key factor to the success of a hydrogen economy [10], [27], [31]. It is important to note that environmental policies differ significantly [7], [9], [34]. Furthermore, hydrogen technologies and their applications may require modification of general energy policy. It is evident that European countries have the most supportive policies and success in exploiting renewable hydrogen energy resources. For example, the UK government is investing $£ 400$ million to support the development and evaluation of the potential for hydrogen as a fuel for ultra-low carbon vehicles in the UK. This programme is called UKH2 Mobility. The objective of the programme is to position the UK to begin the commercial roll-out of hydrogen fuel cell vehicles in 2014/15; similarly Sure4Mobility project is ongoing in Germany. Overall in Europe, European Commission (EC) invests considerably and supports the development, demonstration and deployment of hydrogen technologies. Furthermore, in order to achieve its challenging hydrogen vision EC provides the European hydrogen and fuel cell road map (Fig.1). 


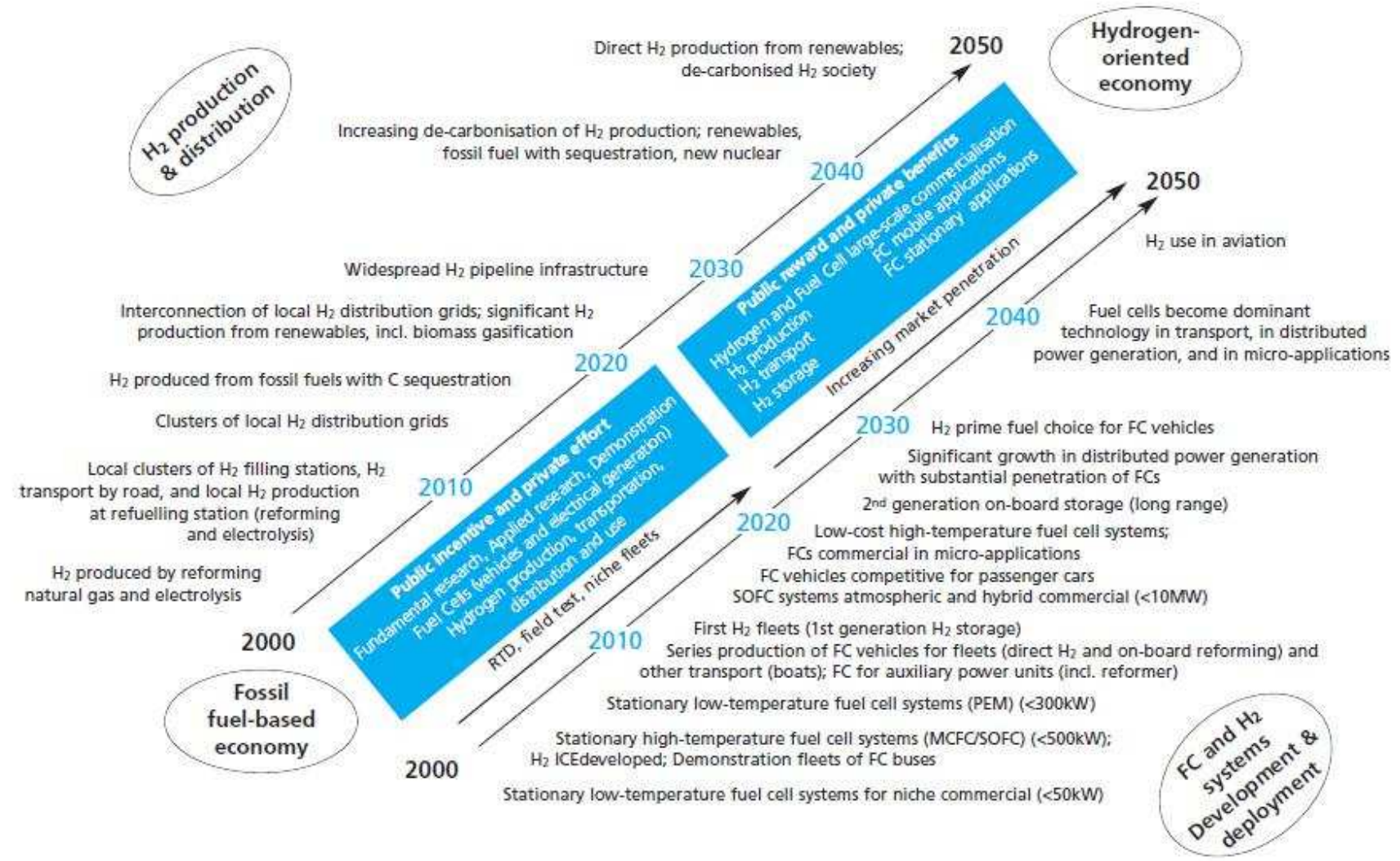

Fig.1.The European hydrogen and fuel cell road map (www.hfpeurope.org/hfp/keydocs)

In addition to this, modification of energy policy towards renewables is suggested via five components third industrial revolution theory [43]. The five components are; shifting to renewable energy, using buildings as power plants, deploying storage, using the internet to transform power grids and electrifying personal transportation. However, it is very difficult to achieve successful transformation by fulfilling one task at a time. The transition must see all of these pillars emerge together. The change is not easy, it is not instant, but it is necessary to solve the energy problems and ensure sustainable development of civilization.

\section{Conclusion}

In this paper, an overview of renewable energy technologies, the hydrogen economy, and the impact of renewable energy technologies penetration on energy price has been presented. In particular, the overview is mainly focused on the hydrogen energy and its impact on energy market. Overall, we move closer to the implementation of hydrogen technologies. It is important to note that appropriate policies are vital to the success of renewable energies, and in particular for the hydrogen economy.

\section{Acknowledgement}

This work was supported by the CymruH2Wales project, part of the Low Carbon Research Institute (LCRI) Convergence Programme. The CymruH2Wales project has been supported by the European Regional Development Fund (EDRF) through the (Llywodraeth Cymru) Welsh Government.

\section{References}

[1] Thanapalan KKT, Zhang F, Procter AD, Carr SJW, Premier GC, Guwy AJ, Maddy J. Development of energy saving mechanism for renewable hydrogen vehicles, Renewable Energy and Power Quality Journal 2012, No.10, 353

[2] UNFCC green house gas inventory report, 2009

[3] Rahman DM, Rahman M, Amin R, Sakhawat NB. A study on renewable energy: A sustainable solution for future energy security, International Journal of Energy Engineering, 2012, vol.2(3), pp.63-68

[4] Hernandez F, Rodriguez C, Hernandez JL. Critical analysis on hydrogen as an alternative to fossil fuels and biofuels for vehicles in Europe, Renewable and Sustainable Energy Reviews, Vol.14, pp772-780, 2010

[5] Zimmerman MB. Learning effects and the commercialisation of new energy technologies-the case of nuclear power. The Bell Journal of Economics, 1982, vol.13(2), pp.297-310

[6] Cherryman SJ, King S, Hawkes FR, Dinsdale R, Hawkes DL. An exploratory study of public opinions on the use of hydrogen energy in Wales, Public Understanding of Science, vol.17, pp.397-410, 2008 
[7] Gross R, Leach M, Bauen A. Progress in renewable energy, Environment International, 29, 2003, 105-122

[8] UNDP/WEC. World energy assessment 2000 - energy and the challenge of sustainability. New York: UNDP, 2000 (ISBN 9211261260)

[9] Herzog AV, Lipman T, Edwards J, Kammen DM. Renewable Energy: A viable choice, Environment, 2001, vol.43(10), pp.8-20

[10] Mackenzie W. Energy production and consumption 2004 (www.woodmac.com)

[11] Anderson D. The economics of photovoltaic technologies. In: Archer M, Hill R, editors, clean electricity from photovoltaic. Imperial College Press, London, 1998, pp.741-771

[12] Williams RH, Terzian G. A benefit/cost analysis of accelerated development of photovoltaic technology. Report No.281, 1993, Centre for Energy and Environmental Studies, Princeton University, USA.

[13] Schwer RK, Riddel M. The potential economic impact of constructing and operating solar power generation facilities in Nevada. 2004, Centre for Business and Economic Research, University of Nevada NREL/SR550-35037

[14] Zhang F, Thanapalan KKT, Maddy J, Guwy AJ. Development of a novel hybrid maximum power point tracking methodology for photovoltaic systems, In the Proceedings of the $18^{\text {th }}$ International Conference on Automation and Computing, Leicestershire, UK, September 2012, pp.1-6

[15] De Vries B. A turn for the better? Innovative concepts for wind energy. Renewable Energy World, April 2001, pp. $42-50$

[16] Smil V. Energy at the crossroad. OECD Global Science Forum Conference, Paris, 17-18 May 2006.

[17] Carr SJW, Thanapalan KKT, Zhang F, Guwy AJ, Maddy J, Gusig LO, Premier GC. Integration of wind power and hydrogen hybrid electric vehicles into electric grids, Sustainability in Energy and Buildings, 2012

[18] Kendall K, Pollet BG, Dhir A, Staffell I, Millington B, Jostins J. Hydrogen fuel cell hybrid vehicles (HFCHV) for Birmingham Campus, Journal of Power Sources, 2011, vol.196, pp.325-330

[19] Thanapalan KKT, Kim JR, Carr SJW, Zhang F, Premier GC, Maddy J, Guwy AJ. Progress in the development of renewable hydrogen vehicles, storage, infrastructure in the UK: Hydrogen centre in its early years of operation, The $2^{\text {nd }}$ International Conference on Intelligent Control and Information Processing, 2011, pp.738-742

[20] Lin Z, Chen CW, Ogden J, Fan Y. The least-cost hydrogen for southern California, International Journal of Hydrogen Energy, 2008, vo.1.33: pp.3009-3014.

[21] Wang W. Production of hydrogen by steam reforming of bio-ethanol over nickel-copper bimetallic catalysts. International Journal of Green Energy, 2009, vol.6(1), pp. $92-103$

[22] Juraschka H, Thanapalan KKT, Gusig LO, Premier GC. Optimization strategies for combined heat and power range extended electric vehicles. International Annual Conference of the German Operations Research Society, (GOR-2012), 4-7 September 2012, Hannover, Germany.

[23] Frid C, Andonegi E, Depestele J, Judd A, Rihan D, Rogers SI, Kenchington E. The environmental interactions of tidal and wave energy generation devices, Environmental Impact Assessment Review, 2012, vol.32, pp133-139

[24] Thorpe T. A brief review of wave energy. AEA technology for the DTI. Crown copyright, 1999.

[25] Kuang C, Huang H, Pan Y, Gu J. A literature review of tidal power generation with coastal reservoir, Advanced Materials Research, 2012, vol.512-515, pp.900-904
[26] Van der Zwaan B, Seebregts A. Endogenous learning in climate-energy-economic models-an inventory of key uncertainties. Energy, Technology and Policy, 2004, vol.2, pp.133-141

[27] United Kingdom, HM Treasury, Stern Review on the Economics of Climate Change, 30 October 2006, ES-v.

[28] McDowell W, Anandarajah G, Dodds PE, Tomei J. Implications of sustainability constraints on UK bioenergy development: Assessing optimistic and precautionary approaches with UK MARKAL. Energy Policy, 2012, vol.47, pp.424-436

[29] Bauen A. Sustainable heat and electricity supply from gasification-based biomass fuel cycles: the case of Sweden and the UK policy. ICCEPT/Fabian Society report, London: ICCEPT, 2001.

[30] Demirbas A. Biofuels sources, biofuel policy, biofuel economy and global biofuel projections. Journal of Energy Conversion and Management, 2008, vol.49, pp.2106-2116

[31] European Commission Report EUR-22002, Introducing hydrogen as an energy carrier: safety, regulatory and public acceptance issues, European Communities, Luxembourg, 2006, pp.1-40

[32] Cherryman SJ, Maddy J, Hawkes FR, Hawkes DL, Dinsdale RM, Guwy AJ, Premier GC. Hydrogen and Wales: A vision of the hydrogen economy in Wales Placing Wales in a position to take full advantage of the hydrogen economy, 2004, vol.3, pp.1-190, University of Glamorgan, UK

[33] Hawkes FR, Hussy I, Kyazze G, Dinsdale R, Hawkes DL. Continuous dark fermentative hydrogen production by mesophilic microflora: Principles and progress, International Journal of Hydrogen Energy, 2007, vo.1.32: pp.172-184.

[34] FCH JU. New energy world: fuel cells and hydrogen for sustainability, 2006 [Accessed 07 January 2013], available at: www.fch-ju.eu

[35] Tsuchiya H, Kobayashi O. Fuel cell cost study by learning curve. Annual meeting of the International Energy Group (EMF/IIASA), 18-20 June 2002 Stanford University, USA.

[36] Tsuchiya H, Kobayashi O. Mass production cost of PEM fuel cell by learning curve, International Journal of Hydrogen Energy, 2004, vol.29(10), pp.985-990

[37] Neij L. Cost development of future technologies for power generation - A study based on experience curves and complementary bottom-up assessments, Energy Policy, 2008, vol.36, pp.2200-2211

[38] Papineau M. An economic perspective on experience curves and dynamic economies in renewable energy technologies, Energy Policy, 2006, vol.34, pp.422-432

[39] Crabtree GW, Dresselhaus MS, Buchanan MV. The hydrogen economy, physics Today, 57(12), 2004, 39-44

[40] Kammen D, Kapadia K, Fripp M. Putting renewable to work: how many jobs can the clean energy industry create?. University of California, Berkeley: Renewable and Appropriate Energy Laboratory (REAL) Report, January 2004, pp.1-25

[41] Morgan J. Comparing energy costs of nuclear, coal, gas, wind and solar. Nuclear Fissionary, April 2010

[42] Blencoe G. Cost of hydrogen from different sources. November 2009 [Accessed 09 January 2013], available at: www.h2carblog.com

[43] Wing J. Hydrogen, fuel cells and the third industrial revolution, Fuel cell today, 20 June 2012, available at: www.fuelcelltoday.com 